\title{
Het kind van de rekening
}

Citation for published version (APA):

ter Weel, B. J. (2012). Het kind van de rekening. Maastricht University. https://doi.org/10.26481/spe.20120907bw

Document status and date:

Published: 07/09/2012

DOI:

10.26481/spe.20120907bw

Document Version:

Publisher's PDF, also known as Version of record

\section{Please check the document version of this publication:}

- A submitted manuscript is the version of the article upon submission and before peer-review. There can be important differences between the submitted version and the official published version of record.

People interested in the research are advised to contact the author for the final version of the publication, or visit the DOI to the publisher's website.

- The final author version and the galley proof are versions of the publication after peer review.

- The final published version features the final layout of the paper including the volume, issue and page numbers.

Link to publication

\footnotetext{
General rights rights.

- You may freely distribute the URL identifying the publication in the public portal. please follow below link for the End User Agreement:

www.umlib.nl/taverne-license

Take down policy

If you believe that this document breaches copyright please contact us at:

repository@maastrichtuniversity.nl

providing details and we will investigate your claim.
}

Copyright and moral rights for the publications made accessible in the public portal are retained by the authors and/or other copyright owners and it is a condition of accessing publications that users recognise and abide by the legal requirements associated with these

- Users may download and print one copy of any publication from the public portal for the purpose of private study or research.

- You may not further distribute the material or use it for any profit-making activity or commercial gain

If the publication is distributed under the terms of Article $25 \mathrm{fa}$ of the Dutch Copyright Act, indicated by the "Taverne" license above, 
Prof. dr. B.J . ter Weel

School of Business and Economics

\section{Het kind van de rekening}




\section{Het kind van de rekening}

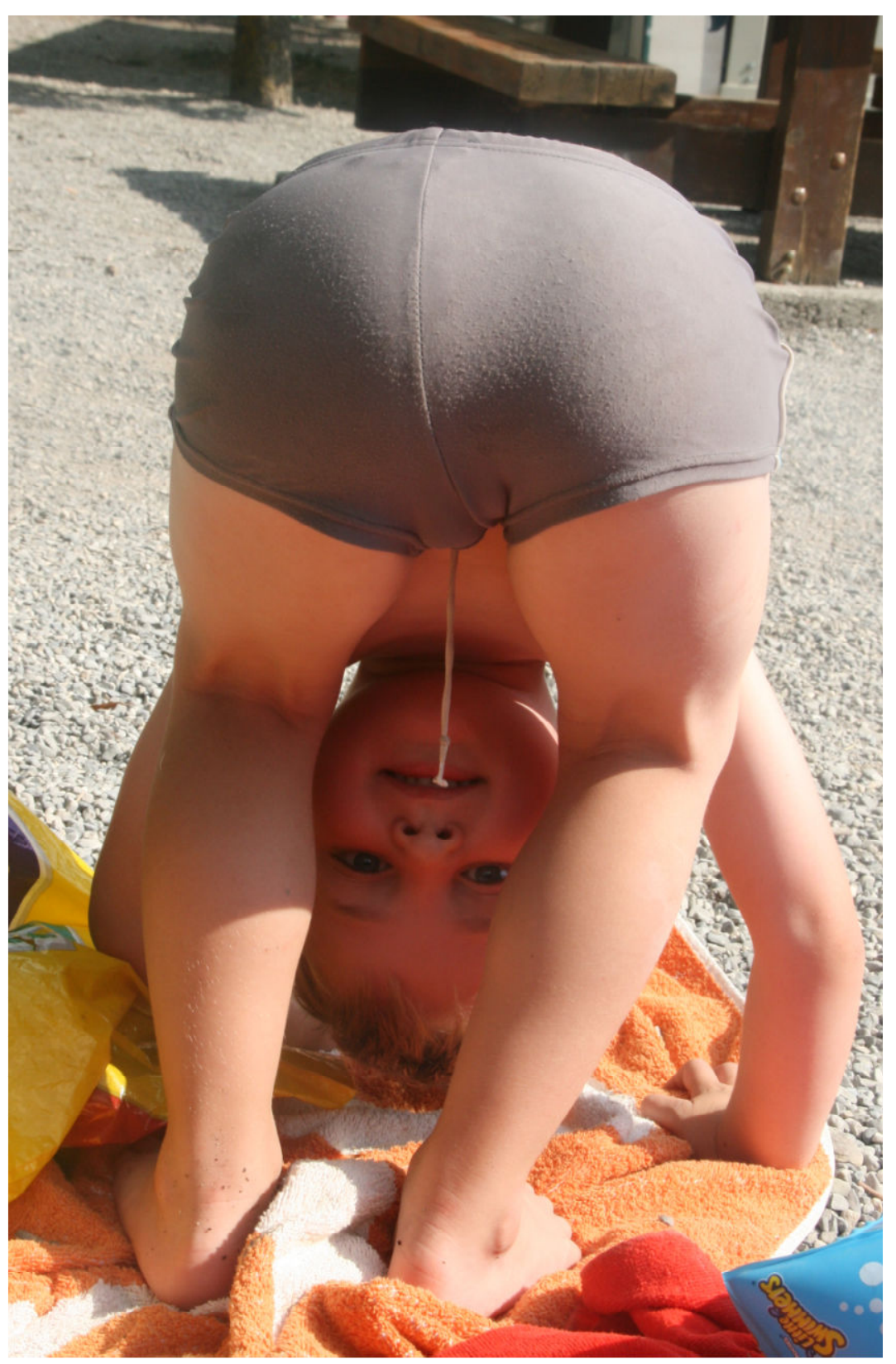

Bas ter Weel 
Rede uitgesproken bij de aanvaarding van het ambt van hoogleraar Social Economics and Labour Market Policy aan de School of Business and Economics van de Universiteit Maastricht

7 september 2012

Prof. dr. B.J. ter Weel

Mijnheer de rector,

Geachte decaan,

Zeer gewaardeerde toehoorders,

Op de kleuterschool was ik lid van gymnastiekvereniging Willen Is Kunnen. Iedere week werd een uurtje gegymd door de kinderen uit het dorp. Het hoogtepunt was de jaarlijkse uitvoering voor ouders en andere familieleden. Dit geschiede op een vrijdagavond ergens in het voorjaar. In de gang van de sporthal stonden alle jongens in hagelwit tenue met blauw embleem te wachten totdat ze hun kunsten mochten vertonen. Ouders die kwamen kijken naar de voorstelling legden alle capriolen zorgvuldig met fotocamera voor het nageslacht vast. In afwachting van het optreden waren ze bijna net zo nerveus als de jonge artiesten. Ik zal u maar meteen bekennen dat ik niet de ster van de avond was. De mars in looppas de zaal in ging nog wel, al liep ik soms wat uit de pas. Ook de sprong door de hoepel was geen probleem. Maar dan de koprol. Ik herinner me nog het kloppende hart in de keel en het malen van het zinnetje "snelle aanloop en kin op de borst". Alle energie was de weken daarvoor gaan zitten in het goed uitvoeren van de koprol. Oefenen op het grasveld in de tuin, goed opletten tijdens de aanwijzingen van de gymlerares en kijken hoe andere kinderen koprolden. Dit was het moment om al die inspanningen te gelde te maken. Het moest nu lukken. Van de koprol zelf weet ik niets meer, maar de glimlach vanaf de tribune herinner ik me nog wel.

Wat leert dit verhaal ons? De naam van de gymnastiekvereniging is zo gek nog niet. Kunnen is voor een groot deel een kwestie van willen. Door energie te steken in de koprol is het gelukt. Daarnaast werden kinderen vanaf leeftijd vier lid van de gymvereniging. Ik werd vier in februari 1979 en de jaarlijkse uitvoering was in de lente van dat jaar. Dit zette mij op een achterstand ten opzichte van klasgenoten die al in het najaar van 1978 lid waren geworden. Zij waren al wat behendiger. Ook het vertrouwen van ouders dat een koprol maken mogelijk is en de hulp bij het onder de knie krijgen van bepaalde vaardigheden is van belang. Ten slotte heb ik geen turntalent, waardoor het geen superkoprol is geworden. 
Waarom is dit verhaal relevant voor mijn leerstoel Social Economics and Labour Market Policy? Het terrein van social economics omvat de economie van alledag. Het onderwijs en het onderzoek op dit terrein aan de School of Business and Economics van de Universiteit Maastricht is gericht op de economie van de nietfinanciële pagina van de krant. Maatschappelijke vragen op beleidsterreinen van onderwijs, innovatie, arbeidsmarkt, veiligheid, cultuur en gezondheid worden geanalyseerd met de prachtige bouwstenen die de economische wetenschap ons biedt. De economie van de kleuter op de gymnastiekvereniging gaat vanuit de invalshoek van social economics over investeren, de kans krijgen om je kunsten te vertonen en het belang van wilskracht om iets voor elkaar te krijgen.

In deze lezing zal ik uitleggen voor welke keuzes kinderen en hun ouders staan, welke belemmeringen kinderen tegenkomen op hun weg naar volwassenheid en dat doorzettingsvermogen belangrijk is om een koprol te kunnen maken. Ik zal dat doen aan de hand van waarnemingen en opvallende verbanden, die leiden tot beleidsuitdagingen en relevant zijn voor de opdracht van mijn leerstoel.

\section{Van kindsbeen af}

Uit eigen ervaring kan ik zeggen dat vader worden één van de hoogtepunten van het leven is. Mijn drie zoons - Joram, Tristan en Beau - maken het leven een stuk mooier en hun ontwikkeling is een fascinerend proces. Over het algemeen geloof ik dan ook dat ouders zielsveel van hun kinderen houden en het beste met ze voor hebben. Deze goede bedoelingen blijven echter niet zonder gevolgen. Jonge kinderen zijn geheel afhankelijk van de ouderlijke liefde en aandacht. Vertaald in economische termen betekent dit dat ze afhankelijk zijn van de investeringen van ouders tijdens de opvoeding. Die investeringen zijn in tijd, zoals aandacht en liefde, maar ook in geld, zoals gezonde voeding en het lidmaatschap van de gymnastiekvereniging.

Afhankelijkheid is een belangrijke beperking voor het kind. Het klinkt $u$ misschien vreemd in de oren, maar het feit dat kinderen hun ouders niet kunnen kiezen is één van de meest fundamentele ongelijkheden in het leven. Je zult maar in de krottenwijken van Rio de Janeiro geboren worden of je zult maar een vader hebben die al voor de geboorte is verdwenen of je zult maar een moeder hebben die waarschijnlijk voordat je vijf jaar oud bent overlijdt aan de gevolgen van aids. Dit zijn schrijnende voorbeelden. Gelukkig hebben kinderen in Nederland niet of nauwelijks met dit soort erbarmelijke omstandigheden te maken in vergelijking met kinderen in delen van Afrika en Zuid-Amerika.

Toch zien we ook in ons land op verschillende terreinen een toenemende polarisatie ontstaan. Een groeiend deel van de Nederlandse kinderen wordt opgevoed onder ongunstige sociale omstandigheden. Van de Nederlandse 
kinderen onder de 16 leefde in 199610 procent in een eenoudergezin. In 2010 was dit 15 procent. Dat is 1 op 7 . Onder de allochtone bevolking is het percentage zelfs gestegen naar 22 procent. In totaal gaat het om ruim 400.000 kinderen die opgroeien zonder de aanwezigheid van beide ouders. Het inkomen van eenoudergezinnen is op dit moment slechts 45 procent van het inkomen van een gezin met twee ouders. In 2000 was dit nog bijna 60 procent. Ruim 15 procent van de Nederlandse gezinnen kan moeilijk rondkomen tegenover ongeveer 10 procent midden jaren tachtig.

Het lijkt erop dat er een verband bestaat tussen een zwakke inkomenspositie en de ontwikkeling van kinderen. Kinderen uit relatief zwakke gezinnen hebben namelijk vaker een taalachterstand wanneer ze het primair onderwijs instromen en een grotere kans om zonder diploma het onderwijs te verlaten.

Figuur 1. Kinderen uit achterstandswijken scoren lager op de Citotoets

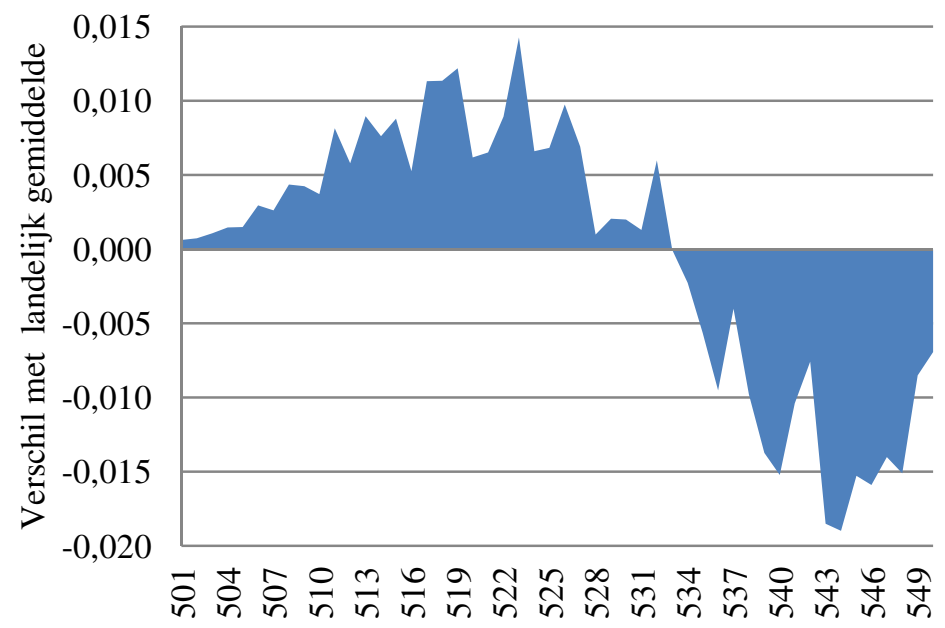

Score op de citotoets (gemiddelde 2006-2008)

Figuur 1 laat als voorbeeld de scores op de Citoeindtoets van kinderen uit de sociaaleconomisch slechtste wijken zien ten opzichte van het Nederlandse gemiddelde. Het gaat hier om de ruim tachtig wijken die op de nominatie stonden om tot vogelaarwijk te worden omgedoopt. Citoscores variëren van 501 tot 550 . Een positief verschil in de grafiek staat gelijk aan een groter aandeel van kinderen uit de slechte wijken met een bepaalde score.

Uit het patroon in de figuur is meteen duidelijk dat deze kinderen slechter scoren op de eindtoets die in groep 8 van het basisonderwijs wordt afgenomen. Bij iedere score hoort een advies voor de middelbare school. Met een score boven 538 is het advies in de regel havo/vwo. Met een score onder 528 is het advies een VMBOopleiding. Ruim 40 procent van de kinderen uit de slechte wijken krijgt op basis 
van deze scores een dergelijk advies, terwijl dit ongeveer 20 procent is voor de rest van Nederland. Tel daarbij op de grotere kans op schooluitval in het VMBO en het is duidelijk dat deze kinderen gemiddeld waarschijnlijk een minder goede toekomst tegemoet gaan.

\section{Jong geleerd, oud gedaan}

Wat betekenen deze ontwikkelingen? Kort gezegd: niet veel goeds. Kinderen in wie onvoldoende wordt geïnvesteerd door te weinig tijd of geld lopen een achterstand op die niet of nauwelijks te repareren is.

Investeringen zijn namelijk het meest rendabel wanneer ze in de eerste levensjaren worden gedaan. Op jonge leeftijd wordt de basis gelegd voor ons latere leven. Deze basis hangt voor een deel af van onze genen. Genen leveren de bouwtekening van waaruit de hersenen zich moeten ontwikkelingen. Daarnaast heeft de baarmoeder waarin we groeien een belangrijke invloed. Als we eenmaal de bouwtekening hebben, moeten er immers materialen komen die het gebouw in elkaar zetten. Ten slotte bepaalt de omgeving waarin we worden geboren voor een groot deel hoe we gaan functioneren. Als het gebouw er eenmaal is, past het zich aan de wensen van de omgeving aan om bewoond te kunnen worden.

Ik illustreer het belang van investeringen aan de hand van voorbeelden uit de topsport. Zulke analyses zijn nuttig, omdat sporters vanaf jonge leeftijd veel hebben geïnvesteerd. Iedere dag, jaar in jaar uit, is gewerkt aan het bereiken van het hoogst haalbare podium. Ouders hebben hun kinderen van wedstrijd naar wedstrijd en van training naar training gebracht en sterk gestimuleerd.

Als eerste heb ik daarom alle teams bekeken die afgelopen zomer aan het - voor Nederland niet bepaald succesvol verlopen - EK voetbal in Polen en Oekraïne hebben deelgenomen. Als ik de deelnemers rangschik op geboortemaand komt er een opvallend patroon bovendrijven. Van de 368 spelers zijn er 106 in de eerste drie maanden van het jaar geboren, tegen 80 in de maanden oktober, november en december. Figuur 2a laat het patroon zien. Nu kan dit berusten op toeval. Daarom heb ik ook de eindklassering van het ProTourklassement in 2011 bekeken. De ProTour is een selectie van de beste professionele wielerteams in de wereld die jaarlijks een competitie van wedstrijden fietsen. De grote klassiekers als LuikBastenaken-Luik, Parijs-Roubaix en de Ronde van Vlaanderen zijn onderdeel van de competitie, evenals de drie grote wielerrondes in Frankrijk, Italië en Spanje. In het eindklassement staan alle renners die punten hebben behaald in 2011. Dit zijn er 229. Als we deze renners ook op geboortemaand rangschikken, vind ik dat 76 renners in januari tot en met maart zijn geboren en slechts 35 in de laatste drie maanden van het jaar. Figuur $2 \mathrm{~b}$ geeft het verband tussen geboortemaand en het aantal renners met ProTourpunten weer. 
Figuur 2. Topsporters zijn vaker vroeg in het jaar geboren

a. Deelnemers aan het EK voetbal in Polen en Oekraïne in 2012 ( $n=368)$

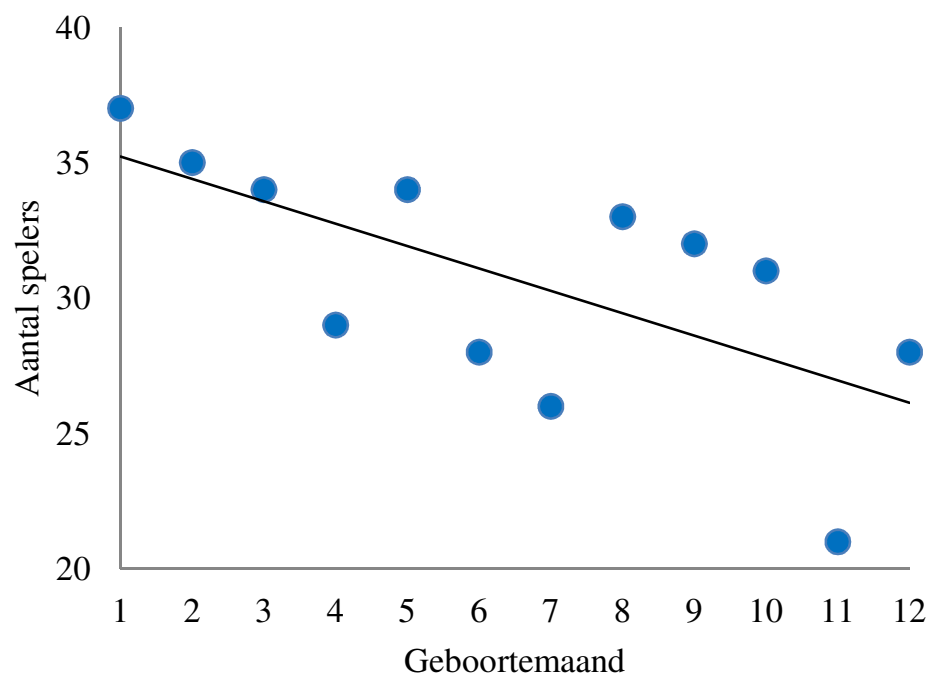

b. Renners met punten in het ProTourklassement over 2011 ( $n=229)$

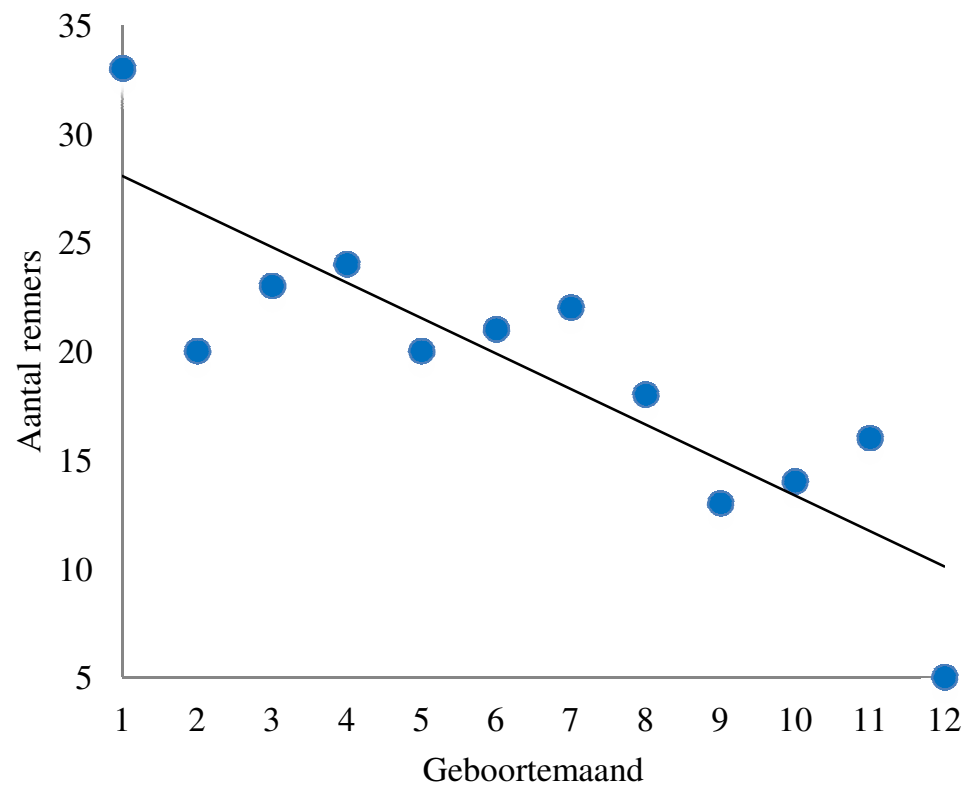

Wat heeft dit nu met investeringen te maken? Veel. Op welke datum denkt u dat de afkapgrens ligt voor sporters in jeugdteams? Juist, op 1 januari. Dit betekent dat een jongen die is geboren op 31 december in een jeugdteam terechtkomt met alleen maar oudere kinderen, terwijl een jongen die op nieuwjaarsdag wordt geboren in een team terecht komt met slechts jongere kinderen. 
Een dag verschil kan een carrière maken of breken, omdat het jonge kind fysiek maar moeilijk kan opboksen tegen de oudere kinderen in het team terwijl het oude kind iedereen fysiek de baas is. Cadel Evans en Fabian Cancellara werden in de jeugd gezien als sterke jongens en reden altijd voorop. Ze waren groter en sterker dan hun leeftijdsgenoten in de jeugdteams van Australië en Zwitserland en wonnen op basis van fysieke kenmerken vele wielerwedstrijden. Ze zijn geboren in februari en maart. Rafael van der Vaart en Ron Vlaar waren toppers in de landelijke jeugdselecties van de KNVB, evenals EK-debutant Jetro Willems. En wat denkt $\mathrm{u}$ ? Geboren in februari en maart.

In ieder cohort hebben oudere kinderen een voordeel ten opzichte van jongere kinderen. Dit betekent dat de selectiedatum bepalend kan zijn voor de investeringen die worden gedaan. Jongens die sterker zijn, worden eerder geselecteerd voor regionale en nationale jeugdteams en komen eerder bij professionele voetbalclubs terecht. In deze selecties krijgen ze training van de beste trainers. Ook oefenen ze met de beste medespelers en wedijveren ze met de beste tegenstanders. De oudere kinderen ontwikkelen zich sneller en bereiken een hoger niveau dan degene die hetzelfde talent hebben, maar toevallig bijna een jaar jonger zijn. Sportbonden zouden daarom beter per half jaar kunnen selecteren.

Terug naar de achterstandswijken in Nederland. In de wijken zelf bestaat ook een effect van selectie. De afkapgrens op de basisschool ligt in Nederland op 1 oktober. Welke kinderen hebben de hoogste Citoscore in groep 8? Inderdaad de kinderen die in het vierde kwartaal zijn geboren. Een eenvoudige analyse waarin de score wordt verklaard uit geboortekwartalen laat zien dat kinderen die geboren zijn in de eerste drie kwartalen van het jaar ongeveer een procent slechter scoren op de Citotoets. Dit verschil loopt op naarmate de kinderen jonger worden. Een kind dat geboren is in het derde kwartaal scoort gemiddeld 1.8 procent slechter dan een kind dat geboren is in het vierde kwartaal. Geboren worden op 30 september of 1 oktober kan dus een wereld van verschil zijn, omdat het kan leiden tot een totaal andere carrière in het voortgezet onderwijs en daarmee het latere leven.

Als we dit vertalen naar investeringen, zijn er twee redenen waarom vroege investeringen hoge opbrengsten hebben. Ten eerste worden vaardigheden die vroeg zijn aangeleerd ingezet in latere periodes. Dit kan direct nuttig zijn, maar stimuleert ook het aanleren van andere vaardigheden. Het leren spreken van een taal is noodzakelijk om te communiceren, maar helpt ook om een tweede taal te leren en om rekensommen beter te begrijpen. Ten tweede bestaat er complementariteit tussen de verschillende dingen die een kind leert. Wanneer nu wordt geïnvesteerd leidt dat tot hogere productiviteit van latere investeringen. Dit 
betekent dat er naast investeringen ook onderhoud gepleegd moet worden. Rekenen en taal vormen de basis van wiskunde. Wanneer dit nu beter wordt aangeleerd, kan later een hoger niveau worden bereikt. Daarvoor is nog steeds een goed begrip van rekenen en taal vereist. Vroege investeringen zijn dus lonend, maar deze moeten wel worden gecontinueerd.

$\mathrm{Bij}$ de voetballers en wielrenners is dit zeker gebeurd. Zij werden vroeg geselecteerd en onder zeer goede condities opgeleid, totdat ze zelf hun brood konden verdienen. Dit staat in schril contrast met de kinderen in achterstandswijken. Zij zijn toevallig in die wijken geboren en zijn als het jongetje dat op 31 december jarig is. Bijna kansloos om tot de selectie van het Nederlands Elftal door te dringen door een toevallige afkapgrens.

\section{Vroege start loont}

Hoe kunnen we realiseren dat ieder kind gelijke investeringskansen krijgt? Dit begint met een simpele notie: "Wie achter de kudde aanloopt, loopt altijd in de stront". Met andere woorden, laten we selectie op basis van het feit dat een kind toevallig in een achterstandswijk is geboren zoveel mogelijk beperken.

Een leerplicht vanaf vier jaar voor iedereen lijkt dus kansrijk. Op dit moment gaan veruit de meeste kinderen vanaf vier jaar naar school, maar begint de leerplicht pas bij vijf. Laten het nu juist de kinderen uit zwakke gezinnen zijn die vaak later op school komen. Het oplossen van deze ongelijke start is eenvoudig door een leerplicht vanaf vier jaar in te voeren. Dit is al eens geopperd en door de Tweede Kamer goedgekeurd, maar door de val van het Kabinet-Kok II controversieel verklaard tijdens behandeling in de Eerste Kamer en later niet doorgezet. De officiële reden voor het afblazen was dat ouders een eigen verantwoordelijkheid hebben om hun kinderen op tijd naar school te sturen. Natuurlijk is dat zo, maar je zult maar domme ouders hebben die je pas vanaf 5 jaar naar de basisschool sturen. Opnieuw een toevalligheid die bepaalde kinderen levenslang op achterstand heeft gezet, zonder dat ze hiervoor zelf een keuze hebben kunnen maken.

Achterstanden zijn echter bij sommige kinderen al op een leeftijd van vier jaar aanwezig. De kosten van opvoeding van een jong kind zijn immers moeilijker te dragen voor armere gezinnen. Deze kosten kunnen worden verlaagd door de inspanningen die de opvoeding vergt te verdelen tussen gezin en overheid. Het blijkt dat investeringen in zeer jonge kinderen uit zwakkere gezinnen en kinderen uit achterstandswijken positief correleren met schoolresultaten en negatief met bijvoorbeeld schooluitval, criminaliteit en drugsgebruik. Uiteindelijk bereiken deze kinderen een betere maatschappelijke positie, die de kosten van het programma ruimschoots overstijgen. Voorschoolse educatie voor bepaalde kinderen lijkt dus zowel effectief als efficiënt. 
Laten we het sommetje voor Nederland eens maken voor kinderen die 2 jaar extra onderwijs krijgen, omdat ze bijvoorbeeld in een achterstandswijk zijn geboren. Deze kinderen gaan voortaan wanneer ze 2 jaar worden 10 uur per week naar een voorschool. Je zou kunnen denken aan 4 ochtenden van half negen tot elf uur. In Nederland kost een gediplomeerde leerkracht die fulltime werkt - met alle toeters en bellen er aan - ongeveer een ton per jaar. Een groep in deze leeftijd bestaat uit 10 kinderen en vergt 2 leerkrachten, zodat er voldoende aandacht is voor ieder kind. Naast onderwijs is er waarschijnlijk ook tijd nodig om een luier te verschonen en na het fruithapje van 10 uur moeten de snoetjes worden gepoetst. Een verhouding van 1 op 5 lijkt dan ook redelijk. Het programma kost dan 5.000 euro per jaar per kind. Als ieder kind twee jaar naar de voorschool gaat, hebben we het in totaal over een investering van 10.000 euro per kind. Dit is geen goedkope interventie en daarom ook waarschijnlijk slechts effectief voor kinderen die achterop dreigen te raken. In Nederland gaat het om ongeveer 50.000 kinderen die in de gevarenzone zitten. Jaarlijks zouden we dus 250 miljoen euro kwijt zijn aan een dergelijk programma.

Dat is een serieus bedrag. Een oordeel over de effectiviteit van dit bedrag kan op twee manieren worden gegeven, waarbij ik het eenvoudig houdt en niet een volledige maatschappelijke kosten-batenanalyse maak. Stel, we doen het niet, wat zijn dan de consequenties? Veel van deze 50.000 kinderen komen terecht op het VMBO of het MBO, zoals de toetsscores uit Figuur 1 laten zien. Schooluitval is daar een groot probleem. Ongeveer 35.000 kinderen vallen ieder jaar uit. Stel dat 20.000 van die uitvallers behoren tot onze risicogroep van 50.000 kinderen. Deze mensen zijn vrijwel kansloos op de arbeidsmarkt en zullen vaker een beroep doen op sociale voorzieningen. Om tot een neutraal effect van het voorgestelde programma voor de voorschool te komen, zouden deze 20.000 uitvallers 12.500 euro in totaal mogen kosten. Een bijstandsuitkering voor een gezin is per jaar al ongeveer gelijk aan dit bedrag. De totale directe kosten zijn waarschijnlijk minstens het dubbele door controle en uitvoeringskosten die gemeentes en centrale overheid moeten maken. Dit alles per jaar per persoon of gezin, terwijl de 10.000 euro slechts eenmalig moet worden geïnvesteerd voor een goede start.

Een tweede oordeel kan worden gemaakt door de arbeidsmarktkansen van deze kinderen te bekijken. Stel dat het programma leidt tot een beter opgeleide beroepsbevolking. Dit heeft een direct positief effect op het inkomen van deze kinderen als ze volwassen zijn, omdat extra onderwijs leidt tot een hoger inkomen en hogere participatie. Daarnaast hebben mensen met een afgeronde opleiding minder kans om zelf in een achterstandpositie terecht te komen. Voor de economie als geheel gaat de productiviteit omhoog en hoeft minder geld te worden besteed aan sociale vangnetten. Waarschijnlijk gaat de criminaliteit ook 
nog eens omlaag evenals de kosten van een ongezonde leefstijl. Ten slotte zal de maatschappelijke participatie stijgen wat de saamhorigheid in de samenleving ten goede komt. Deze effecten gelden jaar in jaar uit en zullen waarschijnlijk substantieel groter zijn dan de initiële investering van 10.000 euro.

Vroege investeringen hebben dus een hoog rendement als we kinderen de kans geven en achterstanden voorkomen is beter dan achteraf herstellen. Snijden in overheidsuitgaven die kinderen belemmeren een eerlijke investeringskans te benutten, zijn daarom maatschappelijk gezien onwenselijk.

\section{Oefening baart kunst}

De volgende vraag is hoe die vroege investeringen er uit moeten zien. Voor de opleiding van topsporters lijkt dat evident en ook het recept om tot een soepele koprol te komen is relatief eenvoudig te bedenken. Het komt allemaal neer op veel oefenen.

De selectievoordelen die het toeval van de geboortedatum biedt, zijn niet genoeg om te verklaren waarom bepaalde kinderen zijn uitgegroeid tot sporthelden en anderen niet. Topsporters hebben natuurlijk onnoemelijk veel uren geoefend toen ze jong waren. Niemand bereikt de top met talent alleen. Druk van ouders en omgeving zijn belangrijk om het talent tot wasdom te laten komen.

Diego Maradona - een van de beste voetballers ooit - is geboren in een sloppenwijk in Buenos Aires. Het is eenvoudig om hier een romantisch verhaal van te maken dat net als het verhaal Pietje Bel begint in de armoede en crisis van de jaren '30 en eindigt als miljonair in Amerika ondanks of juist dankzij allerlei kwajongensstreken. Het werkelijke verhaal van Diego Maradona is dat hij als tienjarig jongetje uit de sloppenwijk werd geplukt door Argentinos Juniors uit Buenos Aires. Dit is een professionele voetbalclub uit de relatief goede wijk La Paternal. Voor aanvang en in de rust van de thuiswedstrijden van Argentinos Juniors moest de jonge Diego de toeschouwers vermaken met zijn balkunsten. Als een soort circusartiest vertoonde hij ongeveer vier jaar bij iedere thuiswedstrijd wat hij met een bal kon. Deze optredens dwongen hem zijn techniek te verfijnen en om te gaan met de druk van een vol stadion. Door zijn talent en volwassenheid debuteerde hij al op zestienjarige leeftijd in de hoogste Argentijnse voetbaldivisie. Tevens was hij op het WK voor spelers onder de 20 jaar in 1979 in Japan de winnaar van de gouden bal. Hij was toen pas 18 , terwijl veel van zijn medespelers en tegenstanders minstens een jaar ouder waren.

Als we dit vertalen naar mijn koprol dan geldt niet alleen dat Willen is Kunnen een juist uitgangspunt voor een gymclub is, maar ook dat willen moet worden gestimuleerd. Een kind wil van nature leren, maar wat het leert hangt af van de 
energie die in bepaalde activiteiten wordt gestoken. Deze energie kan maar eenmaal worden ingezet. Het is daarom logisch dat topvoetballers er op de middelbare school weinig van bakken. Al hun energie gaat richting lichamelijke ontwikkeling. Andere vormen van ontwikkeling worden verwaarloosd.

Het verhaal van de 123 kinderen die werden geselecteerd voor het HighScope Perry Program in de jaren '60 in de Verenigde Staten is een belangrijk voorbeeld van wat het richten van energie kan bewerkstelligen. In een school in het stadje Ypsilanti vlakbij Detroit werden 123 kinderen vanaf 3 jaar iedere dag ongeveer 3 uur onderwezen. Ook was er een controlegroep die dit programma is onthouden. Tevens bezochten de onderwijzers iedere week de gezinnen die in ernstige sociaal-maatschappelijke problemen zaten. Ouders staken weinig energie in hun kroost, omdat ze de handen vol hadden om te overleven. Het effect van het programma is uitgebreid bestudeerd. $\mathrm{Nu}$, ruim 50 jaar later, blijkt dat deze kinderen vaker betaald werk hebben, minder vaak in de gevangenis terecht zijn gekomen en gezonder zijn dan de controlegroep. Een kosten-batenanalyse leidt tot de conclusie dat de verhouding tussen kosten en baten minstens 1 staat tot 5 is.

\section{Er is een grens}

Door veel energie te steken in deze kinderen is dus bereikt dat zij zich beter zijn gaan gedragen. Dit lijkt erg op Diego Maradona die door veel te oefenen de technisch beste voetballer van zijn generatie was. Er is wel een limiet. Een dag heeft immers maar 24 uur en verschillen tussen mensen blijven bestaan. Om deze limiet in beeld te brengen heb ik samen met Lex Borghans en Huub Meijers studie gedaan naar de vraag hoe verschillen in toetsscores tot stand komen. ${ }^{1}$

Om dit te kunnen meten hebben we een experiment gehouden waarin studenten een IQ-test moesten maken. We hebben hierbij de beloning voor een goed antwoord en de tijd die beschikbaar is om een vraag te beantwoorden gevarieerd. Soms krijgen studenten geen financiële beloning voor een goed antwoord en in andere gevallen kan de beloning oplopen tot een euro voor een goed antwoord. Wat we in algemene zin zien is dat studenten meer tijd investeren in het beantwoorden van vragen als ze hiervoor worden beloond. Het feit dat er een beloning is, is belangrijker dan de hoogte van de beloning. Het lijkt er dus op dat mensen harder gaan werken als er een beloning te verdienen is.

Wanneer we de tijd om met een antwoord op de proppen te komen beperken, vinden we dat er een limiet aan harder werken bestaat. Het compenseren door harder te werken, wordt namelijk sterk beperkt door de tijdslimiet. Figuur 3 laat

1 Zie L. Borghans, H. Meijers en B. ter Weel (2008), "The Role of Noncognitive Skills in Explaining Cognitive Test Scores.” Economic Inquiry, vol. 46, pp. 2-12. 
dit zien voor drie gevallen die we hebben bestudeerd. In deze figuur staat de tijdsinvestering op de horizontale as en de fractie goede antwoorden op de verticale as.

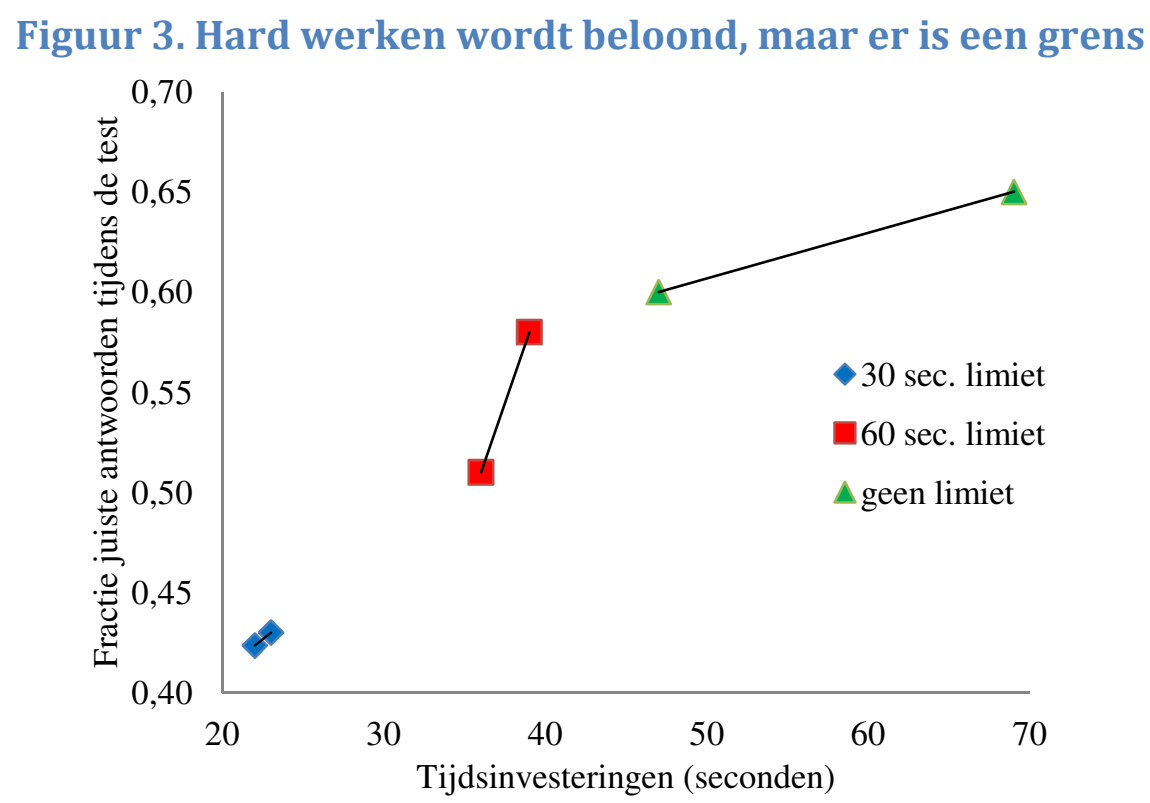

De drie gevallen beschrijven drie tijdslimieten en twee betalingsschema's. De tijdslimieten zijn 30 seconden, 60 seconden en geen limiet. De betalingen zijn niets of een euro voor een goed antwoord. Wanneer we betaalden gingen de scores omhoog. Dit is het gevolg van langer nadenken wat zichtbaar is door een horizontale verschuiving van de bolletjes. Bij een limiet van 30 seconden gaan mensen nauwelijks beter scoren door een financiële beloning, bij de andere limieten wel. Dit is te zien door de verticale verschuiving van de bolletjes.

De oorzaak van de geringere verbetering in resultaten bij een strakke deadline lijkt een gebrek aan tijd.

\section{Zo vader, zo zoon}

Naast energie is de familie van belang om vroege investeringen te stimuleren en te continueren. De geborgenheid van het gezin en het voorbeeld van de ouders vormen de voorkeuren van de kinderen. Deze voorkeuren leiden tot keuzes en uiteindelijk tot gedrag.

Eind januari van dit jaar is Mathieu van der Poel wereldkampioen veldrijden geworden bij de junioren. Hij was net 17 en pas een eerstejaars junior, maar zijn tegenstanders het gehele seizoen al te snel af. De stijl van deze jongen kenmerkt zich door een tomeloze inzet. Kenners vinden niet dat hij mooi op de fiets zit, maar hard gaat het wel. Hij gaat zelfs veruit het hardst van allemaal. 
Mathieu is de zoon van Adri van der Poel en zijn opa is Raymond Poulidor. De laatste is een van de grootste renners ooit. Zijn vader Adri was een succesvolle wielrenner in de jaren tachtig en negentig. In het voorjaar en de zomer was hij actief op de weg en in de winter verdiende hij zijn brood in blubberkoersen. Als iets kenmerkend was voor Van der Poel dan is het zijn wilskracht en doorzettingsvermogen. Hij trainde zo vaak en zo veel kilometers om de beste te zijn dat hij dikwijls overtraind raakte. Niettemin is zijn erelijst indrukwekkend met maar liefst zes klassiekerzeges, twee keer winst in een touretappe en wereldkampioen veldrijden in 1996.

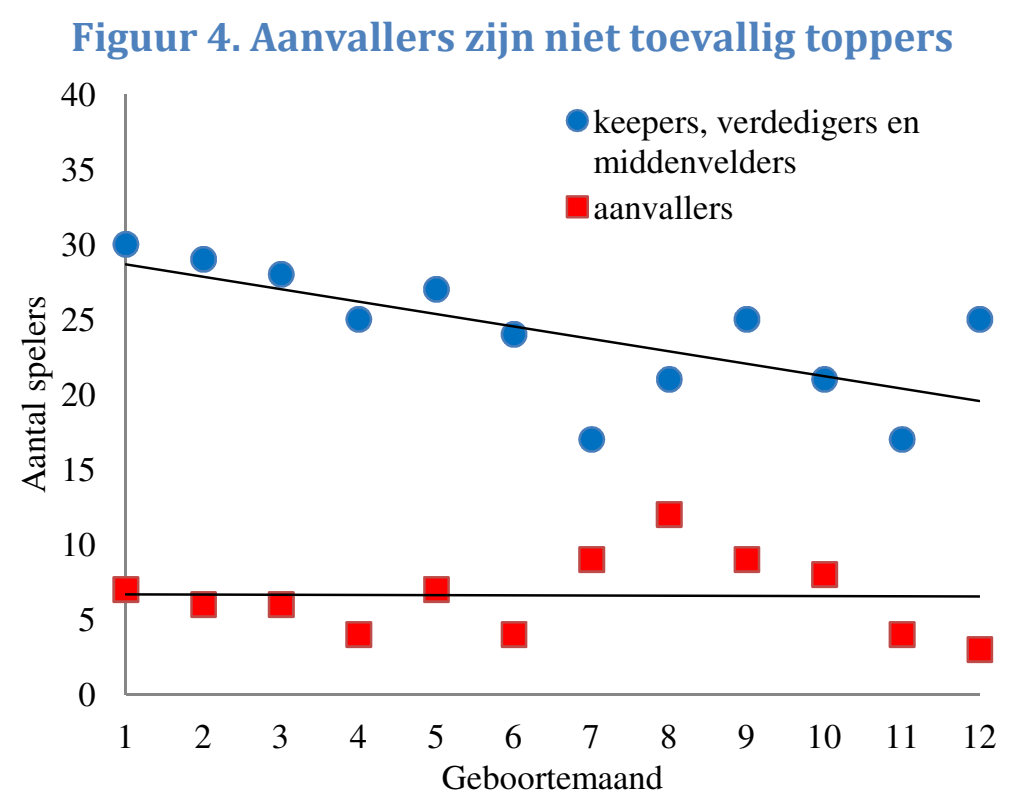

Toevallig? Ik denk het niet. Wilskracht is te trainen en harder werken loont. Als ik de voetballers die actief zijn geweest op het EK van afgelopen zomer opdeel in aanvallers en de rest dan vind ik geen relatie met geboortemaand voor de aanvallers, maar wel voor spelers die op een andere positie spelen (zie Figuur 4). Het zijn juist de aanvallers die moeten vechten voor hun plek in het team. Zij zijn de spelers met het grootste aangeboren talent, maar ook degene die het grootste doorzettingsvermogen moeten hebben om de bal in het doel te krijgen. Ter vergelijking: van de 48 ingeschreven keepers zijn er maar liefst 8 geboren in januari. Op basis van een uniforme verdeling zouden dat er slechts 4 moeten zijn. Fysieke kracht lijkt belangrijker voor een keeper dan een aanvaller.

De rol van ouders is hierbij van belang. Natuurlijk heeft Mathieu van der Poel veel wielertalent, maar zijn vader en opa hebben hem doorzettingsvermogen bijgebracht. Ook de harde cultuur van vallen, gelijk weer opstaan en doorfietsen, die geldt in het wielrennen, is hem met de paplepel ingegoten. 
Voor goede prestaties op school is ook wilskracht en doorzettingsvermogen nodig. Een voorwaarde om te slagen is het op voldoende niveau beheersen van de Nederlandse taal. Ouders zouden daar in moeten investeren door thuis Nederlands met hun kinderen te spreken. In de ruim 80 achterstandswijken waarvoor ik gegevens heb, gebeurt dat slechts in een kwart van de gevallen. In driekwart van de gezinnen leren kinderen dus geen Nederlands van hun ouders. Deze kinderen komen waarschijnlijk met een forse taalachterstand de kleuterschool binnen. De effecten van deze achterstand op toetsscores is fors. Kinderen scoren bijna 2 procent lager dan dezelfde allochtone kinderen die thuis wel Nederlands spreken met hun ouders. De variatie op de schaal van Cito is 50 punten wat neerkomt op gemiddeld 4 punten minder voor kinderen die thuis geen Nederlands met hun ouders spreken. Dit is een groot verschil. Het verschil tussen een VMBO en een Havo-advies is, ter vergelijking, 10 Citopunten.

De effecten van taal op toetsscores geven natuurlijk een beperkt beeld van wat er werkelijk aan de hand is in deze gezinnen. Het is wel zo dat er blijkbaar geen tijd, geld of behoefte is om Nederlands te spreken. Van ouders die in Nederland een bestaan opbouwen mag echter worden verwacht dat ze hun kinderen zo goed mogelijk helpen bij hun investeringen of in elk geval hulp inroepen om hun kinderen een kans op een goede start op school te geven.

\section{Het belang van goede keuzes}

De talenten die we bij geboorte hebben, worden ontwikkeld naar gelang ze door voorkeuren worden geprikkeld. Voorkeuren worden vroeg in het leven gevormd. Hiervoor zijn tijd en middelen nodig om kinderen keuzes te leren maken.

Toen wij in de zomervakantie midden in de nacht de snelweg opdraaiden richting Frankrijk kwam vanaf de achterbank de vraag "zijn we er al bijna?". De gedachte die meteen naar boven komt is dat de tijdvoorkeursvoet van mijn kinderen wat aan de hoge kant is. Hier is niets vreemds aan, want kinderen leven in het heden en hebben weinig besef van de toekomst. Het vermogen afgewogen keuzes te maken, ontwikkelt zich pas later als de prefrontale cortex tot wasdom komt. Niet voor niets halen pubers vaak vreemde capriolen uit.

Dat neemt niet weg dat het beheersen van impulsen en het beter waarderen van de toekomst leidt tot betere keuzes. Mensen die een lagere tijdsvoorkeur hebben, waarderen de toekomst meer en kunnen de toekomst beter overzien. Ze maken betere keuzes en hebben minder vaak spijt. Ook lijkt het er op dat mensen die een goed gevoel hebben voor hun omgeving anderen vertrouwen en een hogere bereidheid hebben een ander te helpen. Het individu en de maatschappij zijn dus beter af als mensen in staat zijn afgewogen keuzes te maken. 
Wat kenmerkt mensen die betere keuzes maken? De resultaten uit het experiment dat ik zojuist besprak geven enig inzicht. We hebben namelijk ook de persoonlijkheid van de deelnemers aan de IQ-test gemeten. Het lijkt er op dat mensen die consciëntieus zijn, onder alle omstandigheden hard werken en minder gevoelig zijn voor financiële prikkels. Hun tijdsinvesteringen en scores zijn namelijk minder gevoelig voor financiële prikkels en tijdsrestricties.

$\mathrm{Nu}$ zou u kunnen denken dat dit aangeboren is. Sommige mensen zijn nu eenmaal consciëntieuzer dan anderen. Dat is zeker waar, maar onze hersenen ontwikkelen zich gedurende de periode van geboorte totdat we volwassen zijn en zelfs daarna worden we nog wijzer. In de vroege periode worden onze capaciteiten gevormd. Deze bestaan uit verschillende dimensies. Onze persoonlijkheid is er een van. Capaciteiten worden ontwikkeld door investeringen en kunnen elkaar aanvullen en versterken, maar zijn soms ook substitueerbaar.

Wanneer capaciteiten complementair zijn, zullen we een sterke mate van specialisatie in ontwikkeling zien. Immers capaciteiten versterken elkaar en duwen ons in een bepaalde richting. Talent plus doorzettingsvermogen creëren topspitsen, zoals Robin van Persie. Capaciteiten kunnen ook substitueerbaar zijn. Dit betekent bijvoorbeeld dat goed je best doen en meer inzet tonen, compenseert voor het gebrek aan aangeboren capaciteiten. Hierdoor wordt een gebrek gecompenseerd door doorzettingsvermogen, waardoor hetzelfde resultaat wordt bereikt. Dirk Kuijt is bijvoorbeeld een minder getalenteerde voetballer dan Robin van Persie. Toch spelen beiden in het Nederlands Elftal. Door meer inzet wordt een relatief gebrek aan aangeboren talent bij Kuijt gecompenseerd. Er is wel een grens. Wat wij hier in de zaal ook gaan doen, profvoetballer worden we waarschijnlijk geen van allen.

\section{Doe eens normaal man!}

In hoeverre voorspellen persoonlijkheidskenmerken op jonge leeftijd latere uitkomsten? Samen met Tyas Prevoo heb ik deze vraag onderzocht door alle Britse kinderen die in april 1970 zijn geboren te bekijken. ${ }^{2}$ We meten persoonlijkheid op zestienjarige leeftijd en relateren dit aan uitkomsten als de personen 34 jaar oud zijn. De uitkomstmaten zijn onder meer lonen, tevredenheid met hoe het leven is gelopen, spaargedrag en ongezond gedrag zoals overgewicht, roken en drugsgebruik.

De resultaten van deze analyse laten zien dat kinderen die consciëntieuzer zijn als ze 16 jaar oud zijn, als volwassenen meer verdienen, meer sparen, gezonder zijn

${ }^{2}$ T. Prevoo en B. ter Weel (2012), "The Importance of Early Conscientiousness for SocioEconomic Outcomes," Werkdocument. 
en minder vaak crimineel gedrag vertonen. Een tweede bevinding is dat er verschillen zijn in de ontwikkeling van kinderen. Een analyse van veranderingen in persoonlijkheid tussen leeftijd 10 en 16 geeft aan dat kinderen die zich minder snel ontwikkelen ten opzichte van de mediaan slechtere uitkomsten hebben. Deze resultaten wijzen op de effectiviteit van vroege en continue investeringen. Wie onvoldoende investeert of van het groeipad valt, is slechter af.

Het is natuurlijk erg verleidelijk om te concluderen dat een training die kinderen consciëntieuzer maakt een nuttige investering is. Dit gaat te snel, omdat we onvoldoende begrijpen van de relatie tussen de uitkomsten die we waarnemen over mensen, hun capaciteiten, keuzes en gedrag. Het werk staat letterlijk en figuurlijk in de kinderschoenen. Een aantal strategieën lijken succesvol:

- Evaluaties laten zien dat kinderen uit achterstandsgezinnen vooral op het maken van keuzes beter zijn gaan scoren na een vroege interventie. Kinderen maken vaker hun opleiding af, komen minder vaak in aanraking met de politie en hebben later vaker een baan. Deze studies zijn vooral in de Verenigde Staten uitgevoerd, maar zijn zowel qua opzet als vergelijkbaarheid niet zomaar toepasbaar op de situatie in Nederland. Daarnaast worden keuzes door voorkeuren gevormd. Blijkbaar is er dus iets met de preferenties gebeurd. Wat dat precies is en hoe de preferenties zijn veranderd, weten we nog onvoldoende.

- Het volgen van individuen over de tijd laat zien dat consciëntieuzere pubers later in het leven meer verdienen, gelukkiger zijn en een gezondere leefstijl hebben. Ook deze studies zijn uitgevoerd met buitenlandse data en niet direct te vertalen naar de Nederlandse context. Dataverzameling in Nederland op dit terrein zou wel kansrijk zijn. Waarom zouden de beleidsmakers op de ministeries van VWS, OCW en SZW niet de krachten bundelen en alle kinderen die in december worden geboren de komend dertig jaar volgen?

- Experimenteel onderzoek in het laboratorium en de combinatie van die gegevens met data uit het veld geeft aan dat mensen met een hogere mate van zelfbeheersing hoger op de maatschappelijke ladder eindigen. Vooral voor Duitsland zijn hier mooie inzichten uit naar voren gekomen.

Werk aan de winkel dus om beter zicht te krijgen op de relevante relaties en mechanismen. Dat is nog niet zo eenvoudig en vergt heel wat wilskracht.

\section{Van wetenschap naar beleid}

Dit werk vraagt samenwerking van beleid en wetenschap. De grote vraag daarbij is hoe we komen van wetenschap naar beleid. Als medewerker van het Centraal 
Planbureau (CPB) en de Universiteit Maastricht bevind ik me dagelijks in beide werelden. Dit is boeiend, maar ook dikwijls een Babylonische spraakverwarring.

Laat ik beginnen met de teleurstelling voor menig wetenschapper. De bevindingen van wetenschappelijk onderzoek zijn slechts een van de vele ingrediënten in de beleidsdiscussie en niet noodzakelijk een heel erg belangrijke. Het belang wordt nog eens verminderd doordat complexe discussies door de politiek worden teruggebracht tot eendimensionale problemen. Helaas bestaat er geen adequaat correctiemechanisme dat fouten van beleidsmakers of politici bij het implementeren van beleid opmerkt en verhelpt. Achteraf gebeurt dat soms wel, zoals we in het onderwijs hebben gezien met bijvoorbeeld de Commissie Dijsselbloem of de Commissie De Wit over de rol van de overheid en toezichthouders in de financiële crisis. Het vertalen van wetenschappelijke inzichten naar concreet beleid vergt scherpe keuzes en het succes hangt af van de kwaliteit van de uitvoering. Zo zijn er voor de invoering van een voorschools programma voor kinderen met een achterstand goede leerkrachten nodig. Toezicht op de invoering en precieze uitvoering van zo'n programma, zoals gebruikelijk is bij het testen van nieuwe medicijnen, zijn tot op heden onvoldoende geborgd. Dit leidt tot verspilling van middelen, omdat de resultaten onbetrouwbaar zijn.

Daarnaast worden wetenschappelijke inzichten waardevoller en aantrekkelijker naarmate er meer onderzoek wordt uitgevoerd. Het hoeft daarbij niet zo te zijn dat ieder onderzoek dezelfde conclusie trekt of dezelfde onderzoekstrategie hanteert. Van de diversiteit aan uitkomsten kunnen we veel leren over het gewicht dat we aan verschillende uitkomsten en methoden moeten toekennen. Op basis van één rapport of een enkele strategie zou daarom nooit beleid mogen worden gevoerd.

In de literatuur zien we een sterke beweging naar het schatten van de directe effecten van beleidswijzigingen. Deze trend is ontstaan omdat het onmogelijk bleek om alle parameters van grote structurele modellen op een adequate manier te bepalen om beleidsvragen te beantwoorden. Samen met de beschikbaarheid van nieuwe databestanden en snellere computers heeft dit geleid tot het schatten van effecten op de marge. Het blijft echter wel belangrijk om de voor- en nadelen van beide manieren te begrijpen. Vragen die goed te beantwoorden zijn met een experimentele analyse zijn vragen als "wat is het effect van prestatiebeloning voor leerkrachten in het primair onderwijs op de toetsscores van leerlingen?" Het is eenvoudig een controle- en behandelgroep te definiëren en de effecten na een tijdje te meten. Dit lijkt op de praktijk in de medische wereld, waarbij moet worden aangetekend dat experimenteren in het veld moeilijker is. Leerkrachten praten met elkaar en worden beïnvloed door de publieke opinie; schoolbesturen hebben te maken met druk van groepen met verschillende belangen. Bij het 
slikken van een medicijn is dat geen probleem, maar bij het meten van gedragsveranderingen wel. Een goed ontwerp, streng toezicht op de besteding van middelen en controle op de uitvoering zijn dus onontbeerlijk.

De toepassing van wetenschappelijke inzichten vergt vaak enige creativiteit. Beleidsmakers en politici willen vaak weten wat het effect van een nieuw programma in de toekomst zal zijn of ze zijn geïnteresseerd in algemene evenwichtseffecten. Dit vergt een structurele aanpak waarbij relaties moeten worden gemodelleerd. Een analyse op de marge of het kopiëren van effecten uit een andere omgeving kan tot grote fouten leiden. Als we bijvoorbeeld alle kinderen van 4 tot 12 jaar een training geven om consciëntieuzer te opereren, neemt het aanbod van mensen die deze capaciteit hebben ontwikkeld toe. De mensen die de training ondergaan worden direct beïnvloed, de rest van de samenleving op een indirecte manier, omdat zij het programma moeten betalen en omdat er nu meer mensen met deze vaardigheid op de arbeidsmarkt komen wat slecht is voor de beloning van de huidige populatie die in deze vaardigheid heeft geïnvesteerd. Hetzelfde argument is van toepassing op de voorschool: niet iedereen profiteert.

Ten slotte gaan politici en journalisten soms aan de haal met onderzoek. Dit is een onderdeel van hun werk. Hierdoor wordt niet altijd het beste, maar vaak het politiek meest haalbare en meest interessante idee uitgevoerd of in de krant afgedrukt. Dit voorjaar riepen de ministers van SZW, OCW en VWS binnen een week - en zonder hun acties te coördineren - jonge ouders op om meer te gaan werken, meer tijd te besteden aan activiteiten op de basisschool en gezonder voedsel op tafel te zetten. Alle drie zwaaiden ze met een dik rapport dat hun gelijk zou bewijzen. $\mathrm{Nu}$ was er met die rapporten niets mis, maar werd vergeten te vermelden dat het om partiële effecten van tijdsbesteding ging. Afruilen waren achterwege gelaten. Jonge ouders moeten echter keuzes maken, want een dag heeft maar 24 uur.

\section{Er is goede hoop}

Tot zover de teleurstellingen. Laat ik besluiten met kansen. Onderzoek heeft een grotere impact naarmate de methoden en technieken gevalideerd zijn en beleidsmakers er van uit kunnen gaan dat de onderzoeker integer en zonder belangen zijn werk heeft gedaan. Debat is daarbij gebruikelijk en effectief, maar men moet niet rollebollend over straat gaan. Een belangrijke trend is richting interdisciplinair onderzoek. Het is belangrijk dat we elkaar begrijpen, maar dat is vaak moeilijk. Economen willen bijvoorbeeld graag welvaartsanalyses uitvoeren, maar dat gaat niet met een analyse op de marge. Het bouwen van een structureel model valt een psycholoog echter zwaar, omdat hij niet gelooft in 
exogeniteitseisen. Hij wil graag het effect van een behandeling op een uitkomst weten en stopt daar. Of de effecten vertaalbaar of breder te interpreteren zijn is niet relevant, want dat vergt een tweede experiment. Meer samenwerking en begrip komen zowel het beleid als de wetenschap ten goede.

Wetenschappelijk onderzoek heeft meerwaarde als het laat zien wat de effecten zijn van beleidsmaatregelen. Sommige voornemens zijn fout en moeten ook worden aangekaart door wetenschappers. Niet alleen het bedenken van vernieuwende ideeën, maar ook evaluaties van beleidsinitiatieven zijn van belang. Ik illustreer dit met een voorbeeld. De Wet Kinderopvang is bedoeld om jonge ouders te stimuleren om te gaan werken door opvang te subsidiëren. Deze opvang heeft geen educatieve functie, want de opvang vindt plaats op basis van minimale kwaliteit en kosten. Toch probeert men op verschillende manieren educatieve elementen in te bouwen. Dat is duur en niet effectief. Ouders die gebruik maken van formele kinderopvang zijn niet de afspiegeling van de samenleving die je wilt bereiken met voorschoolse educatie. Kinderen van hoogopgeleide ouders gaan namelijk vaker naar de kinderopvang dan de kinderen uit de 80 slechtste wijken in Nederland. Deze kinderen hebben nauwelijks baat bij dit soort onderwijs, omdat ze vanuit huis genoeg bagage meekrijgen. Bovendien is een educatief programma duur, omdat het hoogopgeleide medewerkers vergt en een lesmethode. Dit strookt niet met het doel de opvang te regelen tegen minimale kosten en kwaliteit. En, belangrijker nog, de groep die baat heeft bij voorschoolse educatie wordt niet bereikt. Of, zoals Jan Tinbergen ons heeft geleerd, twee doelen worden nooit bereikt met een enkel instrument. Opnieuw een kwestie van het kiezen van de juiste opzet en vervolgens zuivere invoering van het beleid, waarbij wetenschap en beleid elkaar scherp dienen te houden.

\section{Tot besluit}

Dit brengt mij bij het slot van mijn rede. Een koprol op vierjarige leeftijd brengt heel wat teweeg. Dit geldt ook voor ouders, want hun liefde, aandacht en tijd zijn cruciaal voor de ontwikkeling van de hersenen en het gedrag van hun kroost. Vroeg beginnen, achterstanden voorkomen en eerlijke kansen zijn noodzakelijke voorwaarden voor optimale investeringen. Gecombineerd met energie en wilskracht kan iedereen een koprol maken.

Vanuit deze invalshoek zijn de meeste kinderen dus goed af in Nederland. Dit geldt onder de voorwaarde dat de juiste investeringen worden gedaan door ouders. Ouders worden in deze keuzes beperkt door tijd en financiële middelen. De taak van de ouders is die van een goede opvoeding die op tijd moet beginnen. Beleid kan zich het beste richten op het stimuleren van de vroege ontwikkeling, daar waar ouders tekortschieten. Beperkingen van jonge kinderen wegnemen - of ze 
nu het gevolg zijn van toeval of onvoldoende investeringen - is effectief en efficiënt. Vroege investeringen voorkomen voor een groot deel latere problemen als schooluitval, beroep op sociale zekerheid en gezondheidsproblemen die voor de samenleving erg duur zijn. Er zijn ook nog een heleboel zaken die we beter moeten uitzoeken, zowel wetenschappelijk als bij de praktische invoering van maatregelen. Dat zijn fijne prikkels voor de onderzoeker, maar vergt enig geduld van beleidsbepalers.

Een belangrijk doel van mijn leerstoel en het terrein van social economics is om met behulp van de economische gereedschapskist de consequenties van keuzes en gedrag te doordenken. Hierbij kan van alles verkeerd gaan, wat overheidsinterventie legitimeert. Die zelfde overheid kan door maatregelen opnieuw ongelijkheid creëren, zoals afkapgrenzen laten zien. Ik heb nu het voorbeeld van de consequenties van het niet kunnen kiezen van onze eigen ouders uitgewerkt, maar het gaat ook om vragen die segregatie tussen bevolkingsgroepen, gezondheidsinvesteringen en de rol van burgerschap bestuderen. Daarnaast is het onderzoek gericht op het benutten van databronnen. Vandaag heb ik enkele eenvoudige bronnen als voorbeeld benut, maar er zijn er steeds meer en ze worden steeds groter, informatiever en vooral steeds beter. Door koppelingen te maken en verbanden te leggen tussen databronnen en wetenschapsgebieden is het beter mogelijk nieuwe inzichten op te doen die de vragen van beleidsmakers van antwoorden voorzien. De maatschappelijke waarde van ruimhartige toegang tot gegevens van statistiekverzamelaars als het Centraal Bureau voor de Statistiek (CBS) voor wetenschappers en beleidsmakers is bijzonder groot. Deze gegevens worden op dit moment helaas nog onderbenut.

Als docent is het mijn taak slimme en kritische economen op te leiden die met een goed gevulde gereedschapskist helpen bij het oplossen van maatschappelijke vraagstukken. Economie gaat over niets anders dan prikkels en evenwicht. Mensen worden geprikkeld, maken keuzes en die keuzes veranderen prijzen en hoeveelheden. Dit alles op basis van de voorkeuren die al vroeg in het leven worden gevormd. Deze basisprincipes moeten studenten intuïtie bijbrengen om prangende maatschappelijke vragen te doordenken, oorzakelijke verbanden te leggen en deze empirisch te valideren. Ik hoop hier de komende periode binnen de vakgroep Algemene Economie een bijdrage aan te kunnen leveren, zodat we slimme en voor het nationale en internationale beleid doeltreffende economen afleveren.

\section{Dankwoord}

Ik wil tot slot, en volgens goed gebruik, een dankwoord uitspreken. Allereerst wil ik het College van Bestuur van de Universiteit Maastricht bedanken voor het in 
mij gestelde vertrouwen. Het is een eer als hoogleraar te werken aan deze universiteit. In het bijzonder dank ik Joan Muysken en Thomas Dohmen voor hun inzet bij het creëren van deze positie binnen de vakgroep Algemene Economie van de School of Business and Economics.

Sinds ik hier in Maastricht in 1993 ben binnengestapt, heb ik veel geleerd. Mijn eerste stappen in de wetenschap onder leiding van Luc Soete hebben me als onderzoeker gevormd. Als student heeft Luc mij de kans gegeven te werken bij het MERIT. Hier raakte ik geboeid door de economische wetenschap, heb ik het vak geleerd en veel opgestoken van de bonte stoet wetenschappers die in- en uitvlogen. Het is dan ook een genoegen deze rede uit te spreken met Luc als kersverse rector magnificus van deze universiteit.

Ook wil ik graag mijn co-auteurs danken voor het geduld, de tomeloze inzet en het plezier om samen interessante dingen te doen. De samenwerking met Lex Borghans is de meest dierbare. Ik hoop dat we deze samenwerking nog lang te kunnen voortzetten.

Ten slotte heb ik van de CPB-directie veel vertrouwen gekregen om met een team slimme en gemotiveerde economen beleidsanalyses uit te voeren. Dit vraagt heel wat pragmatisme om de dagelijkse praktijk met de economische theorie te verbinden. Het is iedere dag een genoegen om met de economische gereedschapskist in de Haagse werkelijkheid rond te lopen.

Lieve ouders, het is een voorrecht dat jullie hier vanmiddag aanwezig zijn. Met doorzettingsvermogen kom je een heel eind in het leven. Dat heb ik van jullie geleerd. Keuzes maken, hard werken en afmaken waar je aan begonnen bent. Bedankt voor het goede voorbeeld.

Lieve Joram, Tristan en Beau. Er wordt rond dit tijdstip vaak gevoetbald. Dat moeten jullie vandaag missen, maar hopelijk zijn jullie na dit uurtje toch een ervaring rijker. Al was het maar vanwege de bevestiging dat ik de hele dag vreemde kleurplaten op het computerscherm tover en daarbij niet eens mijn mond hoeft te houden. Dat is niets voor jullie. Daarom mogen jullie straks weer lekker rennen.

Lieve Gretel, we kennen elkaar al meer dan een half leven. We zitten in het spitsuur van het leven, maar we vormen een solide team. Ik kan het niet beter samenvatten dan Herman Finkers ooit deed: "We zijn er ons eentje."

Ik heb gezegd. 


\section{Literatuur en bronnen}

De mechanismen die ik in deze lezing heb gebruikt - en de theoretische en empirische onderbouwing hiervan - zijn gebaseerd op zowel wat meer populaire boeken als wetenschappelijke publicaties.

De belangrijkste wetenschappelijke studies die aan de oorsprong van dit betoog liggen zijn:

- Altonji, J.G., F. Hayashi \& L.J. Kotlifkoff (1997), "Parental Altruism and Inter Vivos Transfers: Theory and Evidence," Journal of Political Economy, vol. 105, pp. 1121-1166.

- Baumeister, R.F., E. Bratslavsky, M. Muraven \& D.M. Tice (1998), "Ego Depletion: Is the Active Self a Limited Resource?" Journal of Personality and Social Psychology, vol. 74, pp. 1252-1265.

- Becker, G.S. (1993), "Nobel Lecture: The Economic Way of Looking at Behavior," Journal of Political Economy, vol. 101, pp. 385-409.

- Borghans, L., A.L. Duckworth, J.J. Heckman \& B. ter Weel (2008), "The Economics and Psychology of Personality Traits," Journal of Human Resources, vol. 43, pp. 972-1059.

- Borghans, L., H. Meijers \& B. ter Weel (2008), "The Role of Noncognitive Skills in Explaining Cognitive Test Scores," Economic Inquiry, vol. 46, pp. 2-12.

- Borghans, L. \& B. ter Weel (2003), "Sociaal Kapitaal op het Werk: Vriendelijk, maar Duidelijk," ESB, vol. 88, pp. d14-d16.

- Borghans, L., B. ter Weel \& B.A. Weinberg (2008), "Interpersonal Styles and Labor Market Outcomes," Journal of Human Resources, vol. 43, pp. 815-858.

- Cunha, F. \& J.J. Heckman (2007), "The Technology of Skill Formation,” American Economic Review, vol. 97, pp. 31-47.

- Cunha, F., J.J. Heckman, L.J. Lochner \& D.V. Masterov (2006), "Interpreting the Evidence of Life Cycle Skill Formation," Handbook of the Economics of Education, Elsevier: Amsterdam, pp. 697-812.

- Dohmen T., A. Falk, D. Huffman \& U. Sunde (2010), "Are Risk Aversion and Impatience Related to Cognitive Ability?" American Economic Review, vol. 100, 1238-1260.

- Duckworth, A.L. \& M.E.P. Seligman (2005), "Self-Discipline Outdoes IQ in Predicting Academic Performance of Adolescents," Psychological Science, vol. 16, pp. 939-944.

- Epstein, S. (1994), "Integration of the Cognitive and Psychodynamic Unconscious," American Psychologist, vol. 49, pp. 709-724.

- Gormely, W.T., D.E. Philips \& T. Gayer (2008), "Preschool Programs Can Boost School Readiness," Science, vol. 320, pp. 1723-1724.

- Heckman, J.J. (2001), "Micro Data, Heterogeneity, and the Evaluation of Public Policy: Nobel Lecture," Journal of Political Economy, vol. 109, pp. 673-748. 
- Knudsen, E.I., J.J. Heckman, J. Cameron \& J.P. Shonkoff (2006), "Economic, Neurobiological, and Behavioral Perspectives on Building America's Future Workforce," Proceedings of the National Academy of Sciences, vol. 103, pp. 10155-10162.

- Kochanska, G., K.C. Coy \& T. Murray (2001), "The Development of SelfRegulation in the First Four Years of Life," Child Development, vol. 72, pp. 1091-1111.

- Lebel, C. \& C. Beaulieu (2011), "Longitudinal Development of Human Brain Wiring Continues from Childhood into Adulthood," Journal of Neuroscience, vol. 31, pp. 10937-10947.

- Moffitt, T.E. et al. (2011), "A Gradient of Childhood Self-Control Predicts Health, Wealth, and Public Safety," Proceedings of the National Academy of Sciences, vol. 108, pp. 2693-2698.

- Piana, R.C., W.S. Barnett, M. Bruchinal \& K.R. Thornburg (2009), “The Effects of Preschool Education: What We Know, How Public Policy Is of Is Not Aligned With the Evidence Base, and What We Need to Know," Psychological Science in the Public Interest, vol. 10, pp. 49-88.

- Prevoo, T. \& B. ter Weel (2012), "The Importance of Early Conscientiousness for Socio-Economic Outcomes," Werkdocument.

- Robert, B.W. (2009), "Back to the Future: Personality and Assessment and Personality Development," Journal of Research in Personality, vol. 43, pp. 137-145.

- Sutter, M., M.G. Kocher, D. Rutzler \& S.T. Trautmann (2012), "Impatience and Uncertainty: Experimental Decisions Predict Adolescents' Field Behavior," American Economic Review, te verschijnen.

De wetenschappelijke naslagwerken in boekvorm zijn:

- Becker, G.S. \& K.M. Murphy (2000), Social Economics. Market Behavior in a Social Environment, Harvard University Press: Cambridge.

- Hammerstein, P. (2003), Genetic and Cultural Evolution of Cooperation, MIT Press: Cambridge MA.

- Herrnstein, R.J. \& C. Murray (1994), The Bell Curve. Intelligence and Class Structure in American Life, Free Press: New York.

- Shonkoff, J.P. \& D.E. Philips (2000), From Neurons to Neighborhoods. The Science of Early Child Development, National Academy Press: Washington DC.

De volgende populair wetenschappelijke bronnen zijn gebruikt:

- Baumeister, R.F. \& J. Tierney (2011), Willpower. Rediscovering the Greatest Human Strength, Penguin Books: New York.

- Gladwell, M. (2008), Outliers, Penguin Books: New York.

- Goleman, D. (1995), Emotional Intelligence, Bloomsbury: London.

- Levitt, S.D. \& S.J. Dubner (2005), Freakonomics, Harper Collins: New York. 